\title{
NILAI MANFAAT PARIWISATA EKOSISTEM TERUMBU KARANG TAMAN WISATA PERAIRAN GITA NADA SEKOTONG LOMBOK
}

\author{
Benefit Value of Coral Reef Ecosystem Tourism \\ in The Marine Park Gita Nada Sekotong Lombok
}

\author{
${ }^{*}$ Cornelia Mirwantini Witomo', Nuddin Harahab², dan Andi Kurniawan² \\ ${ }^{1}$ Balai Besar Riset Sosial Ekonomi Kelautan dan Perikanan \\ Gedung BRSDM KP I Lt. 4 \\ Jalan Pasir Putih Nomor 1 Ancol Timur, Jakarta Utara, Indonesia \\ Telp: (021) 64711583 Fax: 64700924 \\ 2Universitas Brawijaya \\ Jl. Veteran, Ketawanggede, Kec. Lowokwaru, Kota Malang, Jawa Timur 65145 \\ Diterima tanggal: 5 Agustus 2020 Diterima setelah perbaikan: 26 November 2020 \\ Disetujui terbit: 23 Desember 2020
}

\begin{abstract}
ABSTRAK
Penelitian ini mengambarkan pola pemanfaatan pariwisata terumbu karang di Taman Wisata Perairan (TWP) Gita Nada dan mengestimasi nilai manfaat ekosistem terumbu karang dengan pendekatan biaya perjalanan sebagai dasar rujukan perencanaan pengembangan kawasan pariwisata di Kabupaten Lombok Barat. Penelitian dilakukan di Taman TWP Gita Nada Sekotong Lombok pada bulan JanuariMaret 2020. Pengumpulan data primer dilakukan dengan cara wawancara menggunakan kuisoner dan observasi segala aktivitas pariwisata yang ada di TWP Gita Nada. Data sekunder dikumpulkan dengan cara penelusuran literatur pada hasil penelitian terdahulu serta publikasi yang dilakukan oleh instansi terkait. Metode analisis yang digunakan adalah Zona Travel Cost Method (ZTCM). Perairan TWP Gita Nada memiliki kombinasi perairan dangkal dengan tipe fringing reefs dan letak TWP Gita Nada yang berbatasan dengan Selat Lombok. Atraksi wisata yang ditawarkan di TWP Gita Nada adalah wisata pantai dan bahari. TWP Gita Nada dengan luas terumbu karang sebesar 1279 ha memiliki nilai manfaat pariwisata Rp3.004.031.073/ha dengan jumlah total pengunjung per 1000 penduduk pada kedua zona adalah sebanyak 51.228 orang. Berdasarkan model fungsi permintaan pariwisata TWP Gita Nada pengembangan kedepan adalah wisata alam yang dikemas menjadi wisata edukasi yang fokus pada anak muda dengan minat belajar tinggi. Perbaikan aksesibiltas dan peningkatan kualitas sarana dan prasarana yang memadai akan menambah daya tarik TWP Gita Nada, dan kedepan lokasi wisata harus mampu memberikan jaminan $2 \mathrm{H}$ yaitu healthy dan hygiene.
\end{abstract}

Kata Kunci: nilai manfaat; pariwisata; terumbu karang; gita nada; Lombok

\begin{abstract}
This study describes the use patterns of coral reef tourism in Marine Park Gita Nada. It estimates the benefit value of coral reef ecosystem with travel cost approach as a reference for planning the development of tourism areas in West Lombok Regency. The research conducted at Marine Park Gita Nada Sekotong Lombok in January to March 2020. Primary data were collected by interview questionnaires and observations of entire tourism activities in Marine Park Gita Nada. Secondary data were collected by literature review on the results of previous research and publications of related agencies. The research used zona travel cost method (ZTCM) analysis. The waters of Marine Park Gita Nada is a combination of shallow water with fringing reef circulation, and Marine Park Gita Nada is located in the border of Lombok Strait. Marine Park Gita Nada offers beach and marine attraction, and coral reefs cover 1279 ha in the area. Marine Park Gita Nada has a tourism benefit value of Rp3,004,031,073/ha with total number of visitors in both zones are 51,228 people per 1000 inhabitants. Based on tourism demand function, the future development for Marine Park Gita Nada would be educational nature-based tourism focusing on young people with high learning interests. Improvement of accessibility and quality of infrastructure will attract more tourists to TWP Gita Nada, and in the future it must guarantee the healthy and hygiene (2H) of the tourism park.
\end{abstract}

Keywords: use value; tourism; coral reefs; gita nada; Lombok 


\section{PENDAHULUAN}

Konsep pengelolaan ekosistem terumbu karang adalah pemanfaatan yang lestari dan dapat dimanfaatkan untuk memenuhi kebutuhan hidup manusia (Selig et al., 2018). Ketika pengelolaan terumbu karang tidak berjalan dengan baik maka akan mengancam ekosistem terumbu karang dan membahayakan fungsi ekologi dan nilai ekonomi bagi masyarakat. Tercatat lebih dari $88 \%$ ekosistem terumbu karang di Asia Tenggara terancam dengan resiko tinggi akibat aktivitas manusia (Hilmi, Safa, Sumalia \& Cinar, 2017).

Ekosistem terumbu karang berfungsi mendukung kehidupan makhluk hidup. Ekosistem terumbu karang memberikan jasa ekosistem berupa habitat untuk berkembang biak, tempat berlindung serta penghalang gelombang besar. Selain fungsi ekologis, terumbu karang sebagai daya tarik pariwisata sehingga memberikan dampak ekonomi kepada masyarakat pesisir. Pariwisata menjadi kegiatan ekonomi penting sebagai kunci pembangunan, kemakmuran dan kesejahteraan (Bayih \& Singh, 2020). Ekosistem terumbu karang erat kaitannya industri pariwisata dengan pengembangan ekonomi khususnya untuk pulau-pulau kecil (Kurniawan, Adrianto, Bengen \& Prasetyo, 2019),

Provinsi Nusa Tenggara Barat telah mencadangkan 252.606 ha sebagai kawasan konservasi perairan daerah dan $48,75 \%$ menjadi Taman Wisata Perairan (TWP). TWP selain untuk kegiatan konservasi memiliki fungsi pengembangan pariwisata berkelanjutan. Pariwisata berkelanjutan memuat aspek keberlanjutan ekologi, dapat diterima secara sosial, adaptif dalam kultural dan menguntungkan secara ekonomis (Arida, 2016). TWP Gita Nada memiliki luas 21.330 ha atau 17\% dari total luas TWP di Propinsi Nusa Tenggara Barat dan dikembangkan menjadi destinasi pariwisata alam Kabupaten Lombok Barat selain Kawasan Sengigi (RTRW Kabupaten Lombok Barat 20112031). Pengembangan ini sejalan dengan program prioritas program strategis pengembangan kawasan pariwisata Provinsi Nusa Tenggara Barat (RPJMD NTB 2019-2023)

Penilaian jasa ekosistem terumbu karang sebagai bentuk estimasi manfaat yang diterima oleh masyarakat dan sebagai alat komunikasi penting untuk informasi dalam pengambilan keputusan (Costanza et al., 2014). Penilaian ini sebagai masukan pemangku kepentingan agar dapat mengambil keputusanlebih baikmenghadapiadanya pilihan untuk memenuhi kebutuhan pembangunan dan upaya mempertahankan kelestarian lingkungan. (Costanza et al., 2017). Penilaian sebagai dasar perencanaan pengembangan pariwisata bersumber dari nilai manfaat pariwisata ekosistem terumbu karang. Adanya nilai manfaat pariwisata ekosistem terumbu karang sebagai bentuk pertimbangan dan dasar tuntutan ganti rugi apabila terjadi kerusakan terumbu karang akibat kelalaian manusia (Phelps, 2014).

Penelitian ini mengambarkan pola pemanfaatan pariwisata terumbu karang di TWP Gita Nada dan mengestimasi nilai manfaat ekosistem terumbu karang dengan pendekatan biaya perjalanan. Secara spesifik tujuan dari penelitian ini adalah untuk menganalisis nilai manfaat pariwisata terumbu karang di TWP Gita Nada sebagai dasar rujukan perencanaan pengembangan kawasan pariwisata di Kabupaten Lombok Barat. Manfaat dari penelitian ini bagi pengelola TWP Gita Nada, pemerintah desa, operator wisata dan masyarakat local adalah untuk memberikan gambaran potensi TWP Gita Nada sebagai destinasi wisata dan kerugian ekonomi apabila terjadi kerusakan ekosistem terumbu karang akibat kegiatan yang tidak ramah lingkungan

\section{METODE PENELITIAN}

\section{Lokasi dan Waktu Penelitian}

Penelitian dilakukan di Taman Wisata Perairan (TWP) Gita Nada (Gili Tangkong, Gili Nanggu dan Gili Sudak) yang terletak di Kecamatan Sekotong Kabupaten Lombok Barat, NTB. Waktu penelitian dilakukan pada bulan Januari - Maret 2020. Kedepan TWP Gita Nada sebagai pengembangan destinasi wisata, memerlukan masukan untuk rencana pengembangan dan antisipasi tekanan terhadap laju degradasi ekosistem terumbu karang. Penelitian ini merupakan bagian dari penelitian tesis penulis berjudul Analisis Instrumen Ekonomi Sebagai Dasar Pengelolaan Kawasan Konservasi Perairan di Taman Wisata Perairan Gita Nada, Lombok Barat NTB.

Kawasan Konservasi Perairan Daerah Taman Wisata Perairan (TWP) Gita Nada memiliki luas areal 21.556 ha dan ditetapkan secara legal dalam Peraturan Bupati Lombok Barat Nomor 56 Tahun 2011 dan termasuk dalam Keputusan Gubernur NTB Nomor 523-640 Tahun 2018 tentang pencadangan kawasan konservasi perairan pesisir 


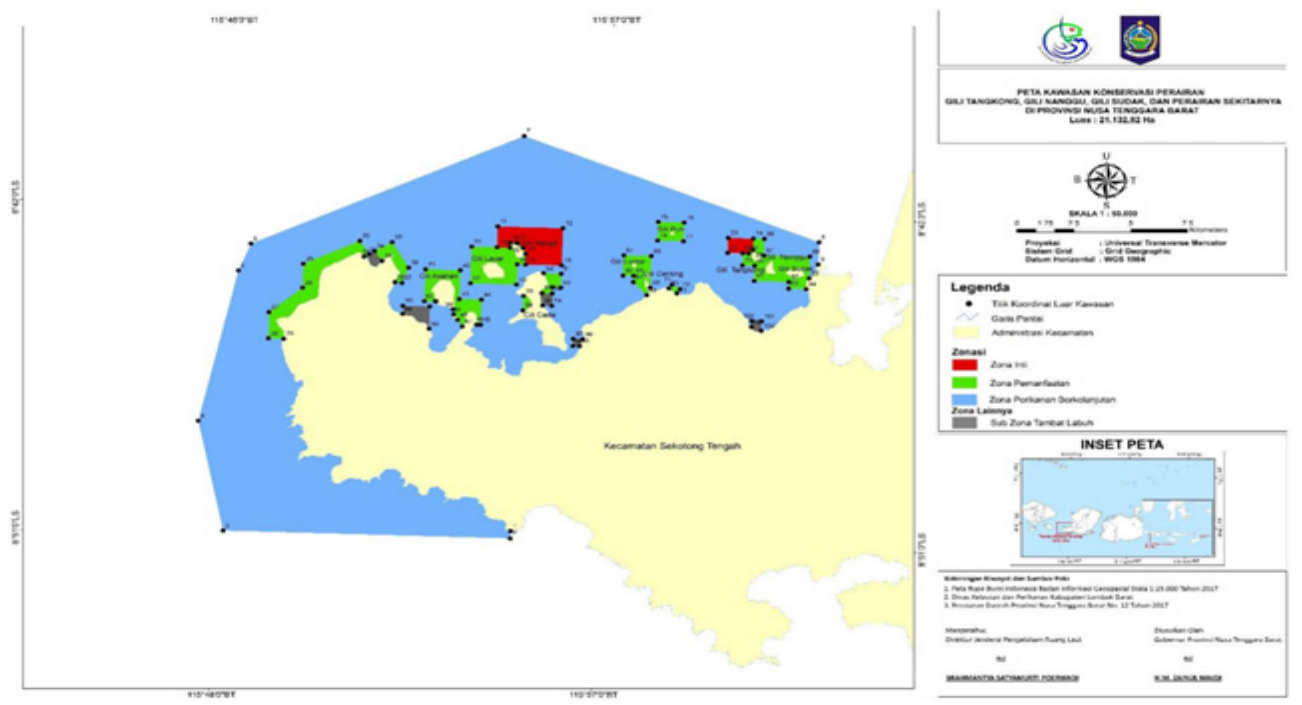

Gambar 1. Peta Lokasi Penelitian.

Figure 1. Map of Research Location.

Sumber: Keputusan Menteri Kelautan Perikanan No 9 - 2018/

Source: Ministry of Marine Affairs and Fisheries Degree Number 9-2018

dan pulau-pulau kecil Provinsi Nusa Tenggara Barat (Gambar 1). TWP Gita Nada terdiri dari zona inti, zona pariwisata, zona perikanan berkelanjutan dan zona pemanfaatan lainnya yang diatur lebih detail dalam Kepmen. Kelautan dan Perikanan No 93/KEPMEN-KP/2018. Aksesibilitas menuju lokasi kajian dapat ditempuh melalui jalur darat dan laut. Jalur darat menuju Kecamatan Sekotong adalah melalui jalan provinsi sepanjang 52 km dari Kota Mataram

Secara administrasi TWP Gita Nada masuk dalam empat desa Kecamatan Sekotong Kabupaten Lombok Barat yaitu Desa Pelangan, Desa Sekotong Barat, Desa Gili Gede Indah dan Desa Batu Putih dengan total luas wilayah administrasi 197,56 ha. Kepadatan penduduk paling tinggi adalah di Desa Gili Gede karena wilayah administrasi seluas 3,75 $\mathrm{Km}^{2}$ sedangkan kepadatan penduduk paling rendah adalah Desa Pelangan dengan wilayah administras seluas $70,11 \mathrm{Km}^{2}$.

\section{Jenis dan Metode Pengumpulan Data}

Teknik pengumpulan data primer dengan wawancara menggunakan kuisoner dan observasi aktivitas pariwisata yang ada di TWP Gita Nada. Sedangkan data sekunder dikumpulkan dari literatur/dokumentasi hasil penelitian terdahulu. Data primer meliputi karakteristik sosial ekonomi, struktur biaya perjalanan, persepsi mengenai kondisi fasilitas pariwisata. Data sekunder meliputi jumlah kunjungan wisatawan tahun 2013-2019 berdasarkan jumlah tamu yang menginap di hotel sekitar TWP Gita Nada, luas ekosistem terumbu karang, jumlah penduduk Kabupaten Lombok Barat dan Kota Mataram. Teknik pemilihan sampling menggunakan teknik stratified random sampling. Teknik sampling ini digunakan untuk pendekatan zonal travel cost method (ZTCM) dengan sampel yang digunakan adalah wisatawan yang berkunjung ke TWP Gita Nada dengan kriteria tertentu. Stratified random sampling menggunakan proses dua tahap untuk membagi populasi menjadi sub-populasi/strata dengan kriteria tertentu untuk menjawab tujuan penelitian (Sugiarto, Hendratono \& Sudibyo, 2015). Teknis pengambilan sampel dengan cara mengelompokan wisatawan yang menjadikan TWP Gita Nada sebagai destinasi wisata utama.

Ukuran sampel yang digunakan dalam penelitian ini menggunakan pendekatan linear time function (LTF) karena pada saat pelaksanaan penelitian tahun 2020, jumlah wisatawan yang berkunjung ke TWP Gita Nada belum diketahui jumlahnya sama dengan penelitian yang dilakukan oleh Mulyati \& Masruri (2019) yang tidak mengetahui populasi wisatawan Kota Bukittinggi dengan pasti. LTF digunakan pada penelitian dengan tidak menggunakan jumlah populasi dalam penentuan sampel sehingga menggunakan estimasi waktu penelitian. Waktu penelitian yang digunakan dalam penelitian iniadalah 6 haripengumpulan data dengan waktu pengisian kuisoner 30 menit untuk waktu 
harian selama 4 jam. Berdasarkan pendekatan LTF maka ukuran sampel yang digunakan dalam penelitian ini adalah 40 orang. Sama halnya dengan penelitian yang dilakukan oleh Nadia (2017) dan Budiman (2019), penentuan ukuran sampel menggunakan LTF untuk menduga nilai manfaat pariwisata berdasarkan biaya perjalanan berdasarkan waktu efektif yang digunakan untuk melakukan penelitian karena jumlah populasi tidak diketahui secara pasti (Sari, 1993) tertuang dalam persamaan berikut:

$$
n=\frac{T-t_{o}}{t_{1}}
$$

\section{Keterangan/Remarks:}

$\mathrm{n}=$ Jumlah responden/Number of respondent

$\mathrm{T}=$ Waktu penelitian (menit)/Time for collecting data (minute)

$\mathrm{t}_{0}=$ Periode waktu harian (menit)/Daily time (minute)

$\mathrm{t}_{1}=$ Waktu pengisian kuisoner (menit)/Time to fill questioner

\section{Metode Analisa Data}

Dalam penelitian ini pendekatan untuk menghitung nilai manfaat pariwisata adalah menggunakan metode biaya perjalanan menurut zona atau zona travel cost method (ZTCM). Menurut Fleming \& Cook (2008), metode biaya perjalanan adalah prosedur non-pasar yang berusaha untuk memberi nilai lokasi wisata dengan menggunakan perilaku konsumsi wisatawan. Secara khusus, biaya yang dikeluarkan untuk menikmati fasilitas rekreasi di lokasi wisata tertentu digunakan sebagai proxy harga; biaya ini dapat mencakup biaya perjalanan, biaya masuk, pengeluaran di tempat dan pengeluaran untuk peralatan modal. Kelemahan dari metode ini adalah tidak bisa digunakan untuk wisatawan yang melakukan perjalanan ke berbagai lokasi wisata dalam satu waktu perjalanan. Wisatawan yang melakukan perjalanan ke berbagai lokasi wisata akan menyebabkan perhitungan menjadi bias (Melstrom, 2015; Mayer \& Woltering, 2018). Metode ZTCM menggunakan informasi tentang jumlah kunjungan ke lokasi wisata dari zona berbeda dengan harga berbeda untuk membangun permintaan lokasi wisata dan mengestimasi manfaat ekonomi dari layanan rekreasi dari lokasi wisata tersebut (Pirikiya, Amirnejad, Oladi \& Solout, 2016). ZTCM lebih banyak digunakan pada lokasi wisata yang baru berkembang namun dengan rentang geografis yang luas (Fleming \& Cook, 2008). Sama halnya TWP Gita Nada sebagai lokasi pengembangan wisata strategis baru memilki luas rentang geografis lebih dari 21.000 ha dengan zona pemanfaatan pariwisata 1.800 ha. Jika ini dibandingkan dengan lokasi wisata lainnya seperti Gili Matra yang merupakan lokasi wisata yang lebih dulu berkembang memiliki luas kawasan 2.954 ha dengan zona pemanfaatan pariwisata seluas 207,49 ha.

Fungsi permintaan pariwisata TWP Gita Nada ditulis dalam persamaan berikut.

$$
\begin{aligned}
\operatorname{lnTrip}= & B_{0}-B_{1} \ln C o s t+B_{2} \ln I n c m+ \\
& B_{3} \ln A g e+B_{4} \ln E d u c+ \\
& B_{5} \ln Q \operatorname{lty}+B_{6} \operatorname{lnZ} \text { ine }
\end{aligned}
$$

\section{Keterangan/Remarks}

$$
\begin{aligned}
\text { Trip }= & \text { Jumlah kunjungan (kali/tahun)/number of } \\
& \text { visit (frequency/year) } \\
\text { Cost } & \text { Biaya perjalanan individu (Rp/tahun) } \\
& \text { personal travel cost (IDR/tahun) } \\
\text { Incm } & \text { Pendapatan (Rp/tahun)/income (IDR/ } \\
& \text { year) } \\
\text { Age }= & \text { Umur (tahun)/age (year) } \\
\text { Educ = } & \text { pendidikan (tahun) /education (year) } \\
\text { Qlty }= & \text { Kualitas ekosistem/quality of ecosystem } \\
\text { Zone = } & \text { Asal wisatawan/origin of tourists }
\end{aligned}
$$

Variabel bebas yang digunakan untuk mengambarkan kunjungan wisata di TWP Gita Nada adalah biaya perjalanan, pendapatan, umur, pendidilkan, kualitas ekosistem, dan asal wisatawan. Perubahan biaya perjalanan yang dikeluarkan untuk menikmati jasa wisata akan mempengaruhi keputusan wisatawan untuk berkunjung (Lundevaller, 2009). Karakteristik sosial ekonomi wisatawan yaitu pendapatan, umur dan pendidikan adalah variabel sosial ekonomi standar yang menjadi perhatian dalam fungsi permintaan kunjungan wisata (Govigli, Gorriz-Mifsud \& Varela, 2019). Nilai untuk kualitas ekosistem diberikan berdasarkan persepsi responden. Kualitas ekosistem adalah gabungan kualitas dari empat ekosistem yaitu terumbu karang, mangrove, padang lamun dan pantai. Kualitas ekosistem menggunakan skala likert dengan kondisi rusak (1) dan kondisi baik (2) jika ditotal dari empat ekosistem maka nilai yang diberikan berkisar dari 4 sampai dengan 8. Untuk asal wisatawan terdiri dari empat zona yaitu dalam Kabupaten Lombok Barat (1), Luar Kabupaten Lombok Barat dalam Propinsi Nusa Tenggara Barat (2), Luar Propinsi Nusa Tenggara Barat (3) dan Luar Indonesia (4). Nilai zona menunjukkan semakin jauh asal wisatawan maka nilai yang diberikan semakin besar. Hal ini mengambarkan bahwa semakin jauh lokasi wisata yang dituju menunjukkan bahwa aktrasi wisata 
yang ditawarkan memberikan manfaat yang tinggi bagi wisatawan (Ezebilo, 2016).

Surplus konsumen menunjukkan nilai ekonomi pariwisata kepada wisatawan. Nilai ekonomi yang diberikan oleh wisatawan memberikan gambaran penting tentang nilai ekosistem di lokasi wisata yang tidak dapat diungkapkan di pasar (Ezebilo, 2016). Total manfaat TWP Gita Nada adalah total surplus konsumen dari setiap zona asal wisatawan. Formula untuk mengestimasi total manfaat TWP Gita Nada tertulis dalam persamaan berikut (Grigalunas dan Congar, 1995-modifikasi)

$V_{i j}=N_{j} x L K_{j}$

$C S_{i j}=\frac{-V_{i j}}{\beta_{i j}}$

$B_{j}=C_{s} x T V_{j}$

$T B=\sum B_{j}$

Keterangan/Remaks

$\mathrm{V}_{\mathrm{ij}} \quad=$ Tingkat kunjungan individu dari zonaper 1000 penduduk/visit level from zone-j per 1000 population

$\mathrm{N}_{\mathrm{j}} \quad$ = Populasi dari zona-j/population from zone-j

$\mathrm{LK}_{\mathrm{j}} \quad$ = Laju kunjungan dari zona-j per 1000 penduduk/visit fraction from zone-j per 1000 population

CS $_{i} \quad=$ Surplus konsumen individu ke-i dari zona -j/consumer surplus person-i from zone-j

$T V_{j} \quad=$ Total kunjungan per tahun dari zona asal ke-j/total visit per-year from origin to zone-j

$\beta_{1 j}=$ Koefisien regresi untuk biaya perjalanan (X1) dari zona ke-j/regression coefficients of travel cost from zone-j

$\mathrm{B}_{\mathrm{j}} \quad=$ Manfaat ekonomi zona ke j/economic benefit from zone-j

TB = Total manfaat ekonomi TWP Gita Nada total value marine park Gita Nada

Dalam penelitian ini dilakukan uji asumsi klasik untuk regresi linear berganda yaitu uji normalitas, uji multikolinearitas, uji heteroskedastisitas, uji autokorelasi. Uji normalitas adalah uji untuk mengetahui apakah data yang dikumpulkan terdistribusi dengan normal. Apabila data yang dikumpulkan tidak terdistribusi dengan normal maka dapat dilakukan uji normalitas non parametrik. Uji Kolmogorov-Smirnov (Formula 7 dan 8) adalah salah satu uji parametrik yang dapat digunakan untuk uji data dengan jumlah sampel kecil dan sampel besar (Oktaviani dan Notobroto, 2014). Apabila nilai maksimum dari selisih $F\left(Z_{i}\right)$ dan $F\left(X_{i}\right)$ lebih kecil dari nilai kritis maka data terdistribusi normal. Uji multikolinearitas (Formula 9) dilakukan untuk mengetahui penduga model yang bias, tidak stabil dan jauh dari prediksinya (Supriyadi, 2016). Semakin tinggi korelasinya (lebih dari 0,8) maka dapat dikatakan adanya multikolinearitas pada model tersebut (Farahani, Rahiminezhad, Same \& Immannezhad, 2010 dan Gujarati \& Porter, 2015).

Ketika suatu model memiliki heteroskedastisitas maka tidak akan menghasilkan estimator yang Best Linear Unbiased dan Estimator (BLUE) dan memberikan kesimpulan yang keliru (Gujarati \& Porter, 2015). Metode eksplorasi kasar uji Park (Formula 10) dapat digunakan yaitu penggunaan kuadrat residual sebagai proksi untuk mengetahui hubungan signifikan antar variabel secara statistik. Apabila tidak ada signifikan ( $p$ value $>0,05$ ) maka dapat simpulkan tidak terdapat heteroskedastisitas (Gujarati \& Porter, 2015). Uji selanjutnya adalah uji autokorelasi dengan pendekatan uji Durbin-Waston (Formula 11) untuk mendeteksi seri korelasi pada model. Pengambilan keputusan mengacu pada kriteria DurbinWaston apakah terdapat gejala autokorelasi positif/negatif atau tidak adanya gejala autokorelasi. Jika mengacu pada tabel DurbinWaston untuk melihat apakah tidak terjadi autokorelasi antara suatu periode tertentu dengan periode sebelumnya apabila nilai hitung DurbinWaston mendekati angka 2 (Fadli, 2016). Formula yang digunakan untuk uji asumsi klasik tertuang lengkap berikut ini:

$$
\begin{aligned}
& Z_{i}=\frac{X_{i}-\bar{X}}{s}, i=1,2,3, \ldots, k \\
& \mathrm{D}_{\mathrm{i}}=\left|F\left(Z_{i}\right)-F\left(X_{i}\right)\right|, i=1,2,3, \ldots, k \\
& r_{x y}=\frac{\sum(X-\bar{X})(Y-\bar{Y})}{\sum(X-\bar{X})^{2} \sum(Y-\bar{Y})^{2}} \\
& \operatorname{Ln} \widehat{U_{1}^{2}}=\ln \sigma^{2}+\beta \ln X_{1}+V_{1}= \\
& \quad \alpha+\beta \ln X_{1}+V_{1} \\
& D W=\frac{\sum_{t=2}^{t=n}\left(\widehat{U_{t}}-\widehat{U_{t-1}}\right)^{2}}{\sum_{t=1}^{t=n}\left(\widehat{U_{t}}\right)^{2}}
\end{aligned}
$$

Keterangan/Remarks

$Z_{i} \quad=$ Nilai normal (sampel) terstandarisasi dari hasil transformasi nilai $\mathrm{X} /$ The standardized normal (sample) value of the transformation of the $X$ value 


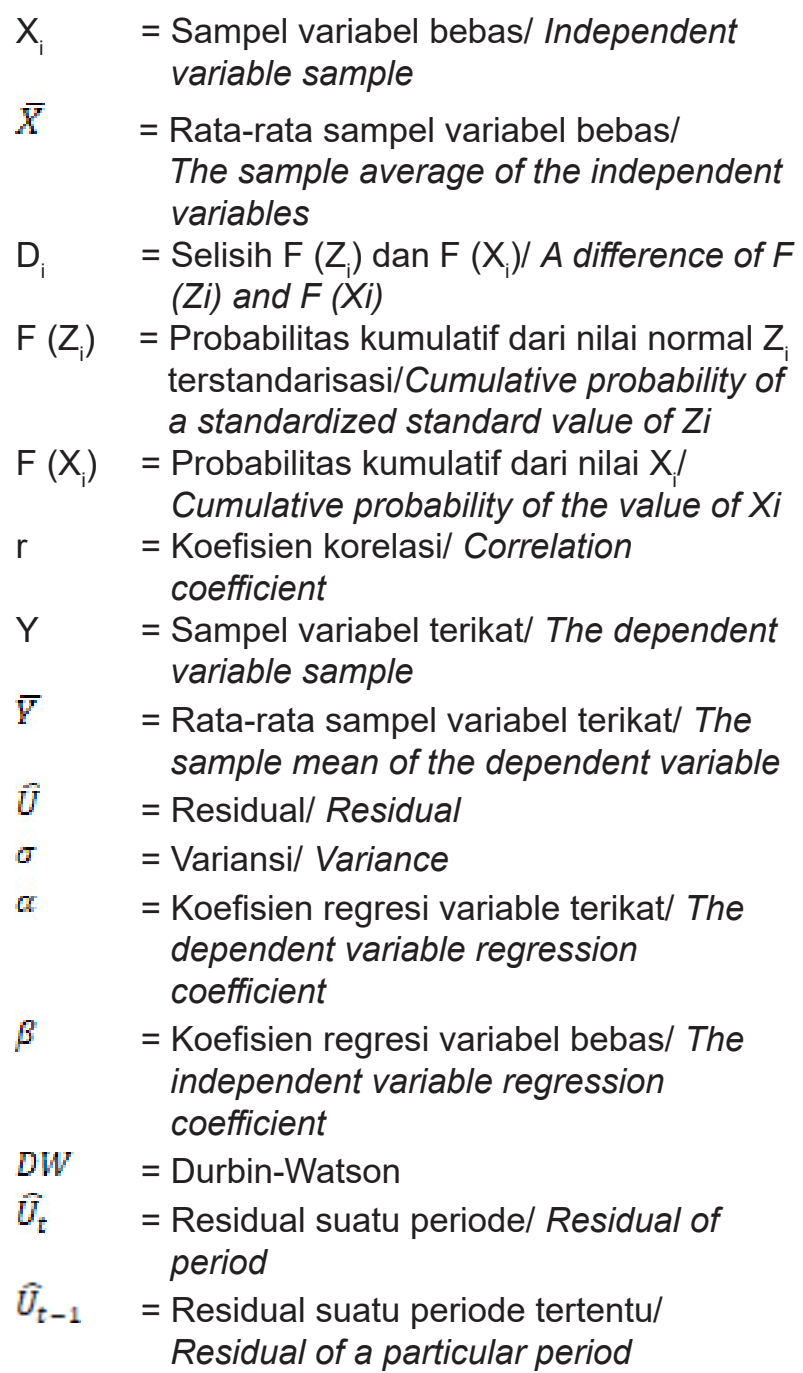

\section{HASIL DAN PEMBAHASAN}

\section{Karakteristik Sosial Ekonomi Responden}

Usia dominan responden pada usia pekerja yaitu berkisar $25-55$ tahun lebih dari $80 \%$ dengan pendapatan di atas 55 juta rupiah pertahun dan didominansi wisatawan lulusan sarjana. Usia dominan wisatawan berkisar 25 - 55 tahun hal ini menunjukkan usia pekerja yang membutuhkan pengalaman untuk berwisata dalam rangka mencari pengalaman menyenangkan yang dapat menambah vitalitas dalam bekerja. Tercatat Gossling, Dwyer, Andersson \& Hall (2015), usia 35-55 tahun adalah usia potensial sebagai target penjualan paket wisata. Usia potensial memiliki kekuatan finansial lebih kuat dan yang memiliki anggaran untuk berwisata dengan kata lain permintaan wisata memiliki batasan biaya yang dikeluarkan untuk berwisata.

Pendapatan wisatawan menjadi faktor pengambilan keputusan untuk berwisata karena secara langsung wisatawan dihadapkan pada biaya yang harus dikeluarkan untuk menikmati atraksi wisata pada periode tertentu. Permintaan wisata berasal dari fungsi utilitas yang tidak langsung yaitu kepuasan maksimun yang didapat oleh wisatawan dari perjalanan ke situs rekreasi ketika wisatawan dihadapkan dengan harga dan besaran pendapatan wisatawan. Hal ini mencerminkan preferensi pengunjung dalam jumlah perjalanan ke lokasi wisata tersebut selama periode waktu tertentu (Ezebilo, 2016). Tingkat pendidikan wisatawan sangat relevan dengan preferensi keputusan dalam berwisata. Kecenderungan kedepan wisata adalah wisata yang bersifat pro lingkungan yang memberikan edukasi dan tantangan bagi wisatawan.

\section{Pola Pemanfaatan Pariwisata Terumbu Karang TWP Gita Nada}

Terumbu karang dengan segala potensi keindahan bawahlautmenjadimodal dasar daya tarik wisatawan (Giyanto et al., 2017). Menurut Pardede, Muttaqin, Tarigan \& Sadewa. (2014), luas terumbu karang yang tersebar pesisir utara Kecamatan Sekotong hingga ke pesisir bagian selatan mencapai 2.249 ha. Secara umum komposisi tutupan substrat ekosistem terumbu karang paling dominan adalah tutupan alga $48,31 \%$ diikuti dengan karang keras
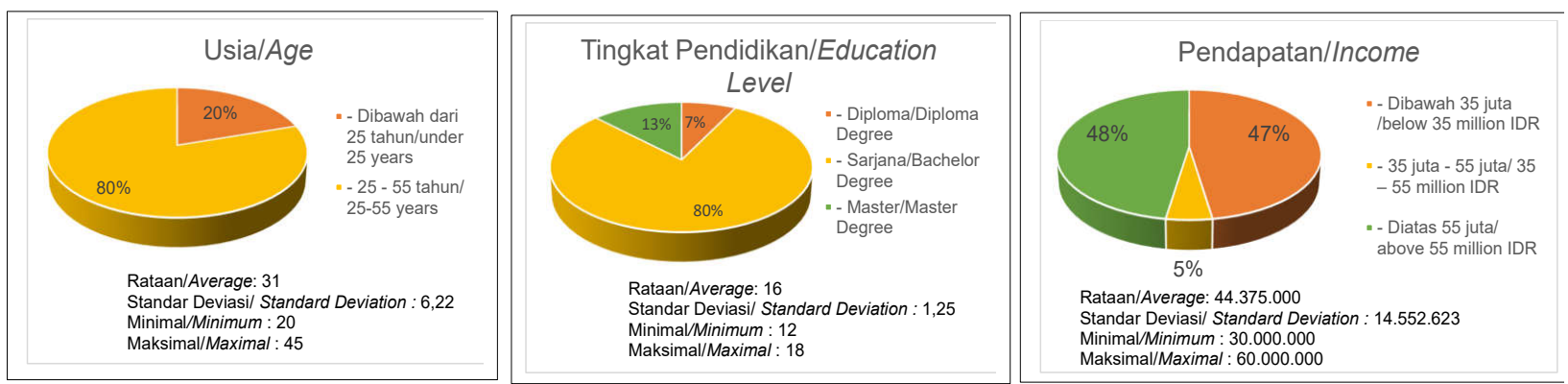

Gambar 2. Diagram Pie Karakteristik Responden ( $n=40$ orang).

Figure 2. Pie Diagram of Respondent Characteristic ( $n=40$ people). 
$35,52 \%$ (Gambar 2). Genera karang yang dominan di perairan TWP Gita Nada adalah karang acropora yang masuk dalam kategori perintis dan memiliki rata-rata pertumbuhan yang lebih tinggi daripada genera karang keras lainnya. Banyaknya alga bisa menjadikan kompetitor bagi terumbu karang yang akhirnya akan menyebabkan terumbu karang mati (Luthfi \& Januarsa, 2018). Tingginya tutupan alga menunjukkan bahwa daerah tersebut banyak karang yang mati karena aktivitas manusia yang tidak ramah lingkungan. Dari hasil penelitian Pardede et al., (2014) menemukan komposisi ikan karang sebanyak 379 spesies dari 43 famili yang dominan berada di perairan Gili Gede. Selain ikan karang ditemukan juga ikan dalam kelompok trofik seperti Caesionidae dan Lutjanidae. Senada dengan penelitian Yulianto, Mawardi \& Purwangka (2018), ikan yang ditangkap oleh nelayan setempat dari famili Acanthuridae, Epinephelidae, Haemulidae, Lethrinidae, Lutjanidae, Scaridae dan Siganidae.

\section{Pola Pemanfaatan Pariwisata Terumbu Karang TWP Gita Nada}

Terumbu karang dengan segala potensi keindahan bawah laut menjadi modal dasar daya tarik wisatawan (Giyanto et al., 2017). Menurut Pardede, Muttaqin, Tarigan \& Sadewa. (2014), luas terumbu karang yang tersebar pesisir utara Kecamatan Sekotong hingga ke pesisir bagian selatan mencapai 2.249 ha. Secara umum komposisi tutupan substrat ekosistem terumbu karang paling dominan adalah tutupan alga $48,31 \%$ diikuti dengan karang keras 35,52\% (Gambar 3). Genera karang yang dominan di perairan TWP Gita Nada adalah karang acropora yang masuk dalam kategori perintis dan memiliki rata-rata pertumbuhan yang lebih tinggi daripada genera karang keras lainnya. Banyaknya alga bisa menjadikan kompetitor bagi terumbu karang yang akhirnya akan menyebabkan terumbu karang mati (Luthfi \& Januarsa, 2018). Tingginya tutupan alga menunjukkan bahwa daerah tersebutbanyak karang yang mati karena aktivitas manusia yang tidak ramah lingkungan. Dari hasil penelitian Pardede et al., (2014) menemukan komposisi ikan karang sebanyak 379 spesies dari 43 famili yang dominan berada di perairan Gili Gede. Selain ikan karang ditemukan juga ikan dalam kelompok trofik seperti Caesionidae dan Lutjanidae. Senada dengan penelitian Yulianto, Mawardi \& Purwangka (2018), ikan yang ditangkap oleh nelayan setempat dari famili Acanthuridae, Epinephelidae, Haemulidae, Lethrinidae, Lutjanidae, Scaridae dan Siganidae.

Wisata bahari yang ditawarkan dalam di TWP Gita Nada adalah menyelam, snorkling, dan wisata memancing. Berdasarkan wawancara spot menyelam terbaik saat ini adalah di Gili Layar dan Gili Rengit. Hal ini dikarenakan karena topografi dasar lautnya yang menantang hingga kedalaman 30 meter dan tingginya keanekaragaman jenis karang serta tingginya jenis biota laut yang eksotis. Snorkling bisa dilakukan diseluruh gili untuk menikmati keindahan bawah laut berupa hamparan terumbu karang, padang lamun, ikan hias dan berbagai biota laut lainnya di kedalaman 2-5 meter. Wisata memancing dapat dilakukan menggunakan perahu namun tidak boleh dilakukan dalam zona pemanfaatan pariwisata. Sedikit berbeda dengan wisata bahari lainnya yang dapat dilakukan di zona pemanfaatan pariwisata namun wisata memancing hanya dapat dilakukan di dalam zona perikanan berkelanjutan. Hal ini diatur dalam Rencana Pengelolaan Zonasi (RPZ) TWP Gita Nada 2016-2036.

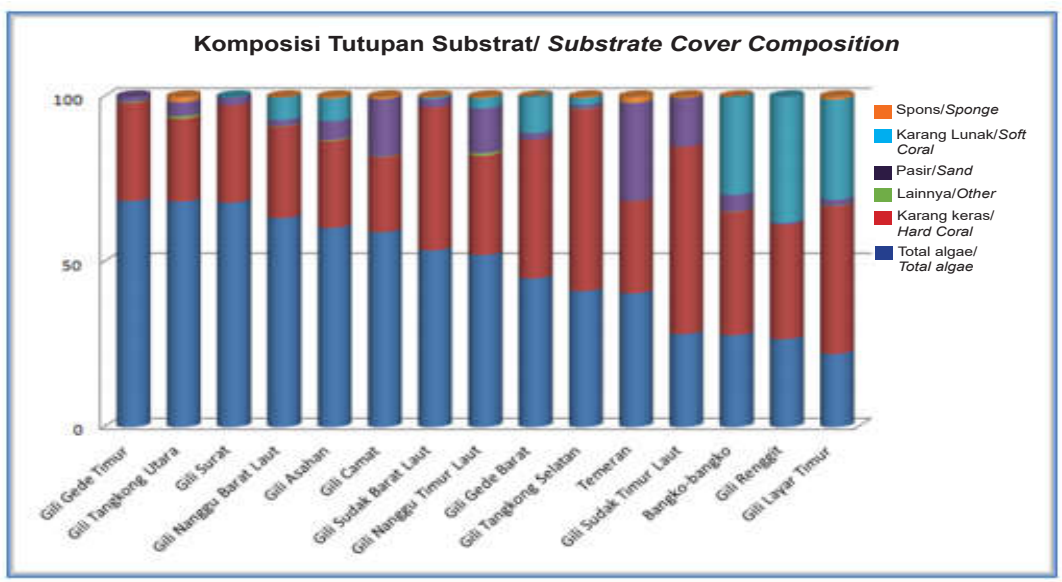

Gambar 3. Komposisi Tutupan Substrat (Sumber : Pardede et al., 2014)

Figure 3. Composition of Substrate Cover (Source: Pardede et al., 2014) 
Atraksi wisata pantai di TWP Gita Nada tidak hanya berada di gili saja namun di pantai yang berada di pulau utama. Wisata pantai yang dimaksud adalah pantai Tawun, pantai Medang, pantai Sekotong Indah, pantai Elak-Elak, pantai Pandanan, pantai Bangko-Bangko. Akses menuju TWP Gita Nada dapat melalui dua jalur yaitu jalur darat dan jalur air. Jalur darat dengan menggunakan transportasi pribadi atau pun dengan transportasi sewaan dari pusat Kabupaten Lombok Barat dapat ditempuh dengan jarak 60 km dalam waktu 1,5 jam. Sedangkan jalur air dengan menggunakan fast boat dari Bali dengan rute Benoa/Sanur-Gili Trawangan-Gili Gede dengan waktu tempuh 2,5 - 3 jam.

Berdasarkan hasil wawancara mengenai tingkat kepuasan pengunjung terhadap sarana prasarana pariwisata TWP Gita Nada, 14 sarana prasarana untuk mendukung pariwisata TWP Gita Nada telah tersedia dengan kondisi berbeda satu sama lain namun perlu penambahan seperti counter pertukaran uang asing dan tower telekomunikasi khususnya di Gili-Gili (Gambar 4). Menurut Kementerian Pariwisata (2015), suatu kawasan pariwisata harus memenuhi 3 A yaitu amenitas, akses dan aktraksi. Amenitas diperlukan untuk memberikan pelayanan kepada para wisatawan untuk menikmati atraksi wisata yang ditawarkan. Amenitas yang ditawarkan adalah kebutuhan dasar seperti akomodasi, restoran, sanitasi, listrik, internet, serta layanan perbankan, fasilitas kesehatan serta amenitas pendukung adalah travel agen, tempat penyewaan pelengkapan wisata, toko cinderamata. Secara umum amenitas adalah segala macam sarana dan prasarana yang diperlukan oleh wisatawan selama berada di daerah tujuan wisatanya (Utari \& Kampana, 2014).

Berdasarkan hasil wawancara mengenai tingkat kepuasan pengunjung terhadap sarana prasarana pariwisata TWP Gita Nada, secara umum kondisi sarana dan prasarana pariwisata TWP Gita Nada cukup baik namun perlu peningkatan kualitas seperti tempat sampah, toilet umum dan tempat ibadah/mushola. Kondisi sarana dan prasarana pariwisata tidak serta merta menunjukkan bahwa telah terpenuhinya kebutuhan permintaan wisatawan namun juga harus masuk dalam kriteria kelayakan untuk meningkatkan daya tarik wisata (Kementerian Pariwisata, 2015). Kondisi sarana dan prasarana pariwisata sebagai salah satu unsur yang berpengaruh dalam pengembangan produk pariwisata (Suwena \& Widyatmaja, 2017) terutama saat ini jika akan mengembangkan produk pariwisata perlu melakukan perbenahan yang memberikan jaminan $2 \mathrm{H}$ yaitu healthy dan hygiene.

Perencanaan strategis kedepan menjadikan TWP Gita Nada sebagai destinasi pariwisata alam oleh pemerintah Kabupaten Lombok Barat selain Sengigi. Hal ini tertuang dalam Rencana Tata Ruang Wilayah (RTRW) Kabupaten Lombok Barat Tahun 2021 - 2031. Kawasan pariwisata alam bertujuan untuk meningkatkan pemanfaatan keunikan, kekhasan dan keindahan alam dan keanekaragaman satwa liar dan tumbuhan yang ada di kawasan wisata alam. Berdasarkan Gambar 5 jumlah kunjungan wisatawan ke TWP Gita Nada dominan berasal dari wisatawan mancanegara. Data kunjungan ini tidak

Ketersediaan Sarana Prasarana Pariwisata/Availability of Tourism Facilities and Infrastructure

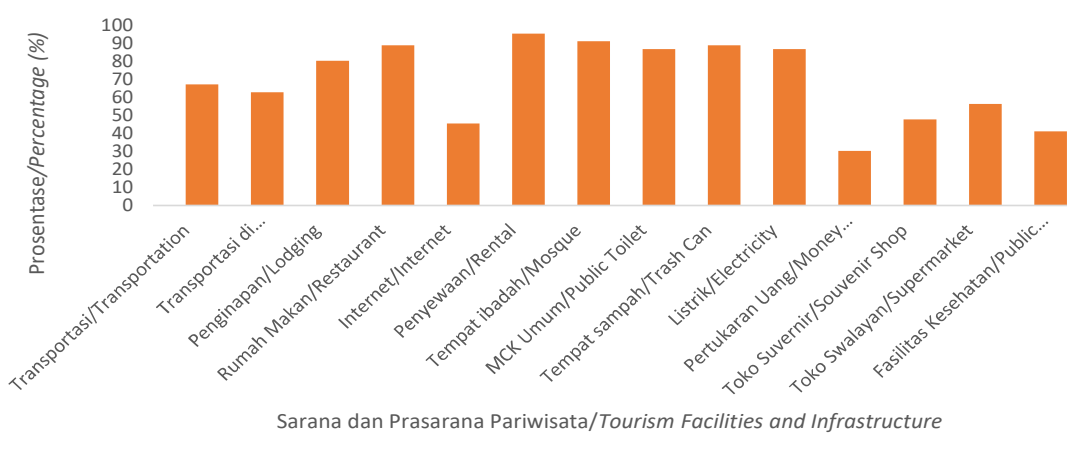

Gambar 4. Ketersediaan Sarana dan Prasarana Pariwisata TWP Gita Nada. Figure 4. Availability of Tourism Facilities and Infrastructure of The TWP Gita Nada.

Data Primer Diolah, 2020/Primary Data Processed, 2020 


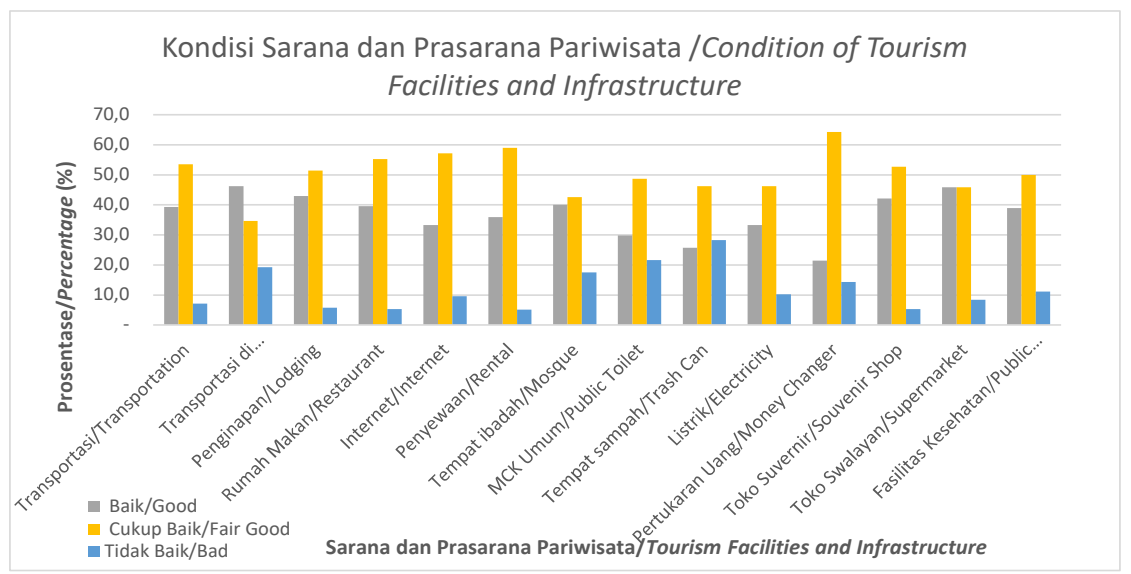

Gambar 5. Jumlah Kunjungan Wisatawan Nusantara dan Mancanegara TWP Gita Nada Tahun 2013-2019.

Figure 5. Number of National and Foreign Tourist Visits of The TWP Gita Nada in 2013-2019.

Sumber : Dinas Pariwisata Kabupaten Lombok Barat, 2019/Source: Tourism Offoce West Lombok Regency, 2019

mencerminkan kondisi sebenarnya karena pendataan hanya pada jumlah tamu yang menginap di beberapa hotel yang ada di Kecamatan Sekotong sehingga menunjukkan bahwa jumlah wisatawan mancanegara lebih tinggi dari pada jumlah wisatawan lokal. Umumnya produk wisata di TWP Gita Nada didominasi oleh wisata alam yang dinikmati dalam waktu enam - delapan jam dan tidak perlu menginap di hotel yang ada di Kecamatan Sekotong.

\section{Nilai Manfaat Pariwisata Terumbu Karang TWP Gita Nada}

Secara umum uji asumsi klasik yang dilakukan dalam penelitian ini menunjukkan data yang digunakan dalam analisis ZTCM tidak terdistribusi normal namun ada dua variabel bebas yang terdistribusi normal. Hal ini berdasarkan uji Kolmogorov Sminov (Tabel 1) dari enam variabel terdapat empat variabel yang tidak terdistribusi normal karena tidak memenuhi kriteria yaitu Probabilitas > dari 0,05. Metode lain yang digunakan untuk melihat data terdistribusi normal adalah dengan melihat grafik histogram dan grafik P-Plot dari model asumsi regresi. Jika melihat Gambar 6 grafik histogram memberikan pola distribusi yang mengikuti pergerakan kurva dan grafik P-Plot terlihat titik-titik yang mengikuti dan mendekati garis diagonal.

Tabel 1. Uji Asumsi Klasik Estimasi Model Fungsi Permintaan Pariwisata TWP Gita Nada.

Table 1.Classical Assumption Test for Estimating the Tourism Demand Function Model of The TWP Gita Nada.

\begin{tabular}{|c|c|c|c|c|}
\hline $\begin{array}{l}\text { Variabel/ } \\
\text { Variable }\end{array}$ & $\begin{array}{l}\text { Uji Kolmogorov-Sminovl } \\
\text { Kolmogorov-Sminov Test }\end{array}$ & $\begin{array}{l}\text { Uji Multikolinearitas/ } \\
\text { Multicollinearities Test }\end{array}$ & $\begin{array}{l}\text { Uji Heteroskedastisitas/ } \\
\text { Heteroskedasticities Test }\end{array}$ & $\begin{array}{c}\text { UjiAutokorelasi/ } \\
\text { Autocorrelation Test }\end{array}$ \\
\hline TRIP & 0.000 & 1 & 0.92 & $\mathrm{DW}=1.779$ \\
\hline COST & 0.103 & -0.57 & 0.29 & \\
\hline INCM & 0.000 & 0.03 & 0.39 & \\
\hline AGE & 0.459 & -0.21 & 0.98 & \\
\hline EDUC & 0.000 & -0.44 & 0.05 & \\
\hline QLTY & 0.005 & 0.42 & 0.76 & \\
\hline \multirow[t]{2}{*}{ ZONE } & 0.000 & -0.46 & 0.54 & \\
\hline & $\begin{array}{l}\text { Data terdistribusi normal } \\
\text { apabila probabilitas lebih } \\
\text { besar dari 0.05. Variabel } \\
\text { INCM, EDUC, QLTY DAN } \\
\text { ZONE tidak terdistribusi } \\
\text { normal/ Data is normally } \\
\text { distributed if the probability } \\
\text { is greater than 0.05. INCM, } \\
\text { EDUC, QLTY AND ZONE } \\
\text { variables are not normally } \\
\text { distributed }\end{array}$ & $\begin{array}{l}\text { Tidak ada } \\
\text { multikolinearitas karena } \\
\text { koefisien korelasi lebih } \\
\text { kecil dari } 0.8 / \text { There is no } \\
\text { multicollinearity because } \\
\text { the correlation coefficient } \\
\text { is smaller than } 0.8\end{array}$ & $\begin{array}{l}\text { Tidak adan Heter } \\
\text { oskedastisitas karena p } \\
\text { value lebih besar dari } 0,05 \\
\text { (tidak signifikan) kecuali } \\
\text { EDUC nilainya setara } \\
\text { dengan } 0.05 / \text { There is no } \\
\text { heteroscedasticity because } \\
\text { the } p \text { value is greater } \\
\text { than } 0.05 \text { (not significant) } \\
\text { except the EDUC value is } \\
\text { equivalent to } 0.05\end{array}$ & $\begin{array}{l}\text { Tidak terjadi autokorelas } \\
\mathrm{dL}<\mathrm{d}<\mathrm{dU} \\
\mathrm{dL}=1.119 \\
\mathrm{dU}=1.924 \\
\text { Mendekati angka 2/There } \\
\text { is no autocorrelation } \\
d L<d<d U \\
d L=1.119 \\
d U=1,924 \\
\text { Approaching number } 2\end{array}$ \\
\hline
\end{tabular}

Sumber: Data Primer Diolah (2020)/Source: Primary Data Processed, (2020) 


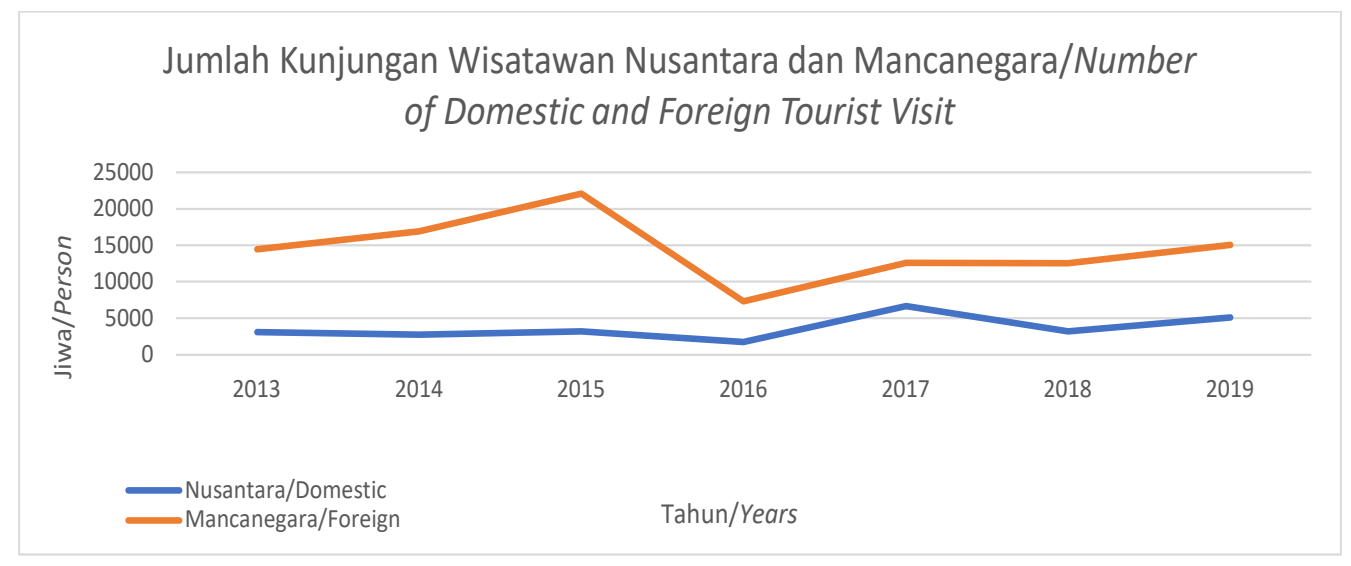

Gambar 6. Grafik Histogram dan Grafik P-Plot Estimasi Model Fungsi Pariwisata (Data Primer Diolah, 2020). Figure 6. Histogram and P-Plot Graph of Tourism Demand Estimation Model (Primary Data Processed, 2020).

Uji multikolinearitas menunjukkan bahwa koefisien korelasi pada model ini lebih kecil dari 0,8 dan dapat diambil kesimpulan bahwa data tidak ada multikolinearitas atau dengan kata lain tidak jauh dari prediksinya. Uji heteroskedastisitas dengan melihat hubungan residual tidak signifikan pada model ini karena semua variabel bebas memiliki $P$ value $>0,05$. Uji autokorelasi untuk melihat seri korelasi dari residual pada model ini tidak ditemukan autokorelasi karena nilai Durbin Watson mendekati dua. Berdasarkan uji asumsi klasik yang telah dilakukan menjadi dasar pengambilan keputusan untuk membangun model permintaan pariwisata TWP Gita Nada dengan menggunakan beberapa asumsi (Gambar 7).

Model fungsi permintaan pariwisata TWP Gita Nada mengacu dan modifikasi dari hasil penelitian Ezebilo (2016) yaitu jumlah trip (TRIP) dipengaruhi oleh biaya perjalanan (COST), pendapatan (INCM), umur (AGE), pendidikan (EDUC), persepsi kondisi ekosistem TWP Gita Nada (QLTY) dan asal wisatawan (ZONE). Berdasarkan hasil regresi berganda menggunakan SPSS.16 estimasi model fungsi permintaan pariwisata TWP Gita Nada tertuang dalam Tabel 2.

Dari hasil analisis regresi linear berganda konsep dasar pendekatan travel cost method sudah memenuhi asumsi dasar bahwa koefisien variabel COST bernilai negatif (-) karena hubungan jumlah kunjungan berbanding terbalik dengan biaya perjalanan. Konsumen memiliki pertimbangan untuk memanfaatkan barang dan jasa berdasarkan kegunaan dengan mengingat biaya yang harus dikeluarkan untuk memperoleh manfaat dari barang dan jasa tersebut (Lundevaller, 2009). Senada dengan Loomis et al., 2015) mengungkapkan koefisien biaya perjalanan bernilai negatif sesuai dengan teori ekonomi.
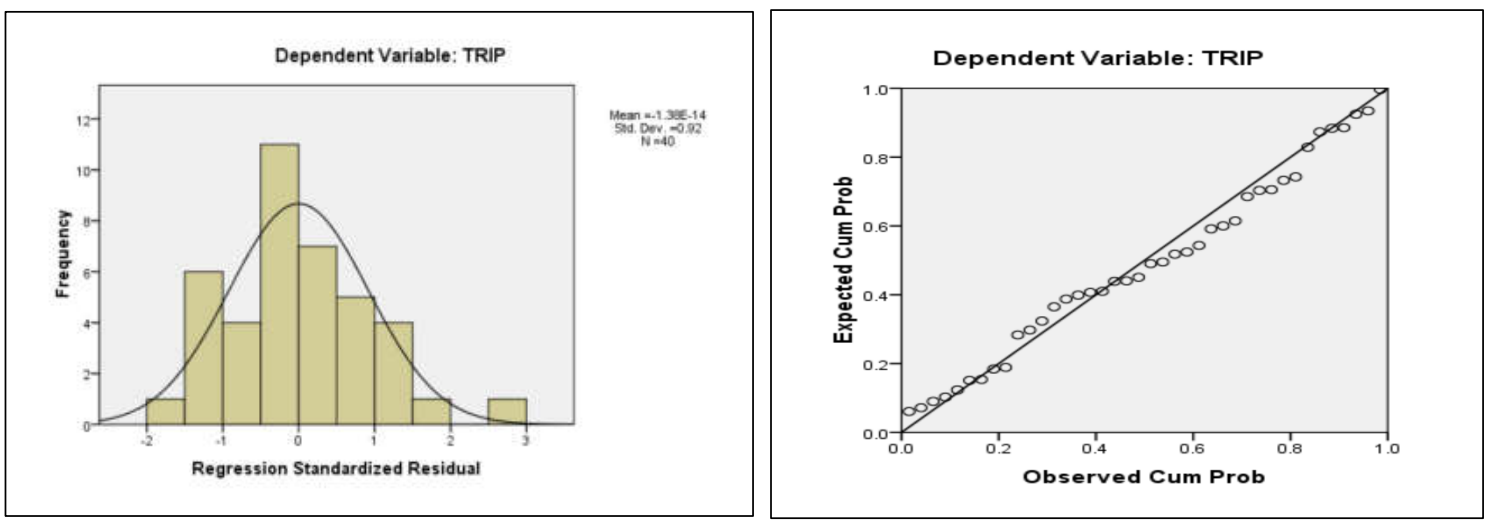

Gambar 7. Grafik Histogram dan Grafik P-Plot Estimasi Model Fungsi Pariwisata. Figure 7. Histogram and P-Plot Graph of Tourism Demand Estimation Model.

Data Primer Diolah, 2020/Primary Data Processed, 2020. 
Tabel 2. Estimasi Model Fungsi Permintaan Pariwisata TWP Gita Nada.

Table 2. TWP Gita Nada Tourism Demand Estimation Model.

\begin{tabular}{lcccc}
\hline $\begin{array}{c}\text { Variabel/ } \\
\text { Variable }\end{array}$ & $\begin{array}{c}\text { Koefisien/ } \\
\text { Coefficient }\end{array}$ & $\begin{array}{c}\text { Standar Error/ } \\
\text { Std. Error }\end{array}$ & $\begin{array}{c}\text { Rataan/ } \\
\text { Mean }\end{array}$ & $\begin{array}{c}\text { Standar Deviasi/ } \\
\text { Standard Deviation }\end{array}$ \\
\hline TRIP & 0.145 & 2.070 & 0.173 & 0.303 \\
COST & -0.099 & 0.041 & 13.788 & 1.325 \\
INCM & 0.397 & 0.107 & 17.542 & 0.335 \\
AGE & -0.441 & 0.165 & 3.430 & 0.203 \\
EDUC & -1.410 & 0.374 & 2.765 & 0.089 \\
QLTY & 0.039 & 0.227 & 1.873 & 0.168 \\
ZONE & -0.246 & 0.143 & 0.948 & 0.361 \\
\hline$R^{2}$ & & & & \\
Adjusted R & 0.651 & & \\
Std Error & 0.588 & & & \\
F Statistic & 0.196 & & & \\
Prob F Stat & 10.268 & & \\
Durbin Watson & 0.000 & & \\
\hline
\end{tabular}

Model ini memiliki adjusted $\mathrm{R}$ square sebesar 0,582 atau model ini hanya bisa menjelaskan $58,2 \%$ faktor yang memiliki pengaruh terhadap kunjungan wisata TWP Gita Nada sedangkan $41,8 \%$ tidak dapat dijelaskan menggunakan model dalam penelitian ini. Jika melihat nilai dari probabilitas lebih kecil dari 0,05 menunjukkan variabel bebas dalam model memberikan pengaruh terhadap jumlah kunjungan TWP Gita Nada.

Jika melihat lebih dalam pada masingmasing variabel bebas sebagai contoh koefisien INCM bernilai positif, menunjukkan setiap ada penambahan pendapatan memberikan pertimbangan individu untuk melakukan perjalanan ke TWP Gita Nada. Koefisien positif lainnya yaitu QLTY dengan kata lain semakin tinggi kualitas ekosistem pesisir memberikan pertimbangan yang positif untuk melakukan perjalanan ke TWP Gita Nada. Dari perspektif kebijakan QLTY berpengaruh terhadap pendapatan industri wisata apabila ada penurunan kualitas ekosistem (Lankia, Neuvonen dan Pouta, 2017). Oleh karena itu perlu menekankan pentingnya kegiatan rehabilitasi dan konservasi ekosistem dan melarang kegiatan-kegiatan yang dapat merusak ekosistem di TWP Gita Nada.

Koefisen ZONE berbanding terbalik dengan jumlah kunjungan TWP Gita Nada. Asumsi yang bisa diambil adalah semakin dekat tempat tinggal wisatawan dengan TWP Gita Nada maka pertimbangan melakukan perjalanan lebih besar daripada wisatawan yang jarak tinggalnya dengan TWP Gita cukup jauh. Jarak tempuh yang dekat akan memberkan pertimbangan tidak membutuhkan waktu yang banyak untuk menikmati atraksi wisata sehingga memberikan pertimbangan untuk melakukan perjalanan ke TWP Gita Nada. Sama halnya dengan penelitian yang dilakukan oleh Saengavut (2018), menganggap bahwa nilai dari waktu perjalanan dan jarak ke lokasi wisata tidak berpengaruh besar sehingga tidak dimasukan dalam model karena sebagian besar responden tinggal di dekat lokasi wisata. Untuk perspektif kebijakan kedepan dalam rangka meningkatkan jumlah kunjungan wisata ke TWP Gita Nada ketika mengadakan event-event seperti Hari Bumi atau Hari Nusantara sebaiknya memilih target wisatawan lokal dengan waktu dan jarak tempuh yang dekat (terutama penduduk Kabupaten Lombok Barat dan Kota Mataram).

Hal menarik lainnya dari model ini adalah variabel AGE dan EDUC berbanding terbalik dengan kunjungan wisata TWP Gita Nada. Berdasarkan hasil pengamatan dilapangan umur responden yang berkunjung paling muda 20 tahun sedangkan paling tua berumur 45 tahun atau dapat dikatakan TWP Gita Nada sebagai wisata alam diminati oleh kalangan anak muda kategori usia angkatan kerja. Sama halnya dengan hasil penelitian Saengavut (2018), koefisien umur negatif menunjukkan wisata alam menarik lebih banyak wisatawan muda. Tingkat pendidikan responden paling rendah mengenyam pendidikan 12 tahun dan paling tinggi mengenyam pendidikan 18 tahun (Iulusan program Master). Jika melihat koefisien EDUC seolah-olah asumsi yang dibangun semakin rendah tingkat pendidikan wisatawan akan meningkatkan kunjungan TWP Gita. Berdasarkan 
koefisien EDUC perspektif kebijakan kedepan dalam rangka meningkatkan tingkat kunjungan wisatawan, pengelola atau pelaku industri wisata TWP Gita Nada mampu mengemas atraksi wisata yang memberikan edukasi sehingga wisatawan dapat menambah wawasan ketika menikmati estetika alam.

Estimasi nilai manfaat pariwisata TWP Gita Nada dalam hal surplus konsumen yang dapat dihitung sebagai kebalikan dari koefisien biaya perjalanan. Analisis ZTCM TWP Gita Nada mengambarkan hubungan tingkat kunjungan per 1000 penduduk pertahun dengan total biaya perjalanan setiap zona. Jumlah zona dalam analisis ini terdiri zona Lombok Barat dan Mataram dengan pertimbangan sebagian besar responden wisatawan berasal dari dua wilayah tersebut. Secara lebih detail perhitungan regresi tertuang dalam Tabel 3.

Berdasarkan persamaan regresi linear antara tingkat kunjungan per 1000 penduduk pertahun dengan biaya total perjalanan setiap zona, maka dapat diketahui tingkat permintaan pengunjung terhadap TWP Gita Nada dengan berbagai simulasi alternatif terkait harga tarif masuk kawasan atau tarif penyewaan alat wisata. Adanya penetapan harga tarif akan mempengaruhi tingkat kunjungan per 1000 per tahun dari setiap zona. Kenaikan positif tarif akan diikuti dengan penurunan jumlah kunjungan. Cara untuk mendapatkan tingkat kunjungan per 1000 penduduk pertahun dengan berbagai kemungkinan tarif pada masing-masing zona adalah dengan menambah tarif baru ke dalam biaya total perjalanan dari setiap zona kemudian dimasukan ke dalam persamaan regresi linear antara tingkat kunjungan per 1000 penduduk pertahun dengan biaya total perjalanan setiap zona ( $\mathrm{V}=1,324+0,00041 \mathrm{X})$ dan hasilnya dikalikan dengan jumlah penduduk di setiap zona yang kemudian dibagi dengan seribu. Penambahan tarif baru tersebut terus dilakukan hingga pengunjung tidak mau membayar atau tidak ada lagi kunjungan. Secara lebih detail perhitungan simulasi tarif masuk nilai surplus wisatawan TWP Gita Nada tertuang dalam Tabel 4.

Tabel 4. Perhitungan Simulasi Nilai Surplus Pengunjung TWP Gita Nada.

Table 4. Calculation of Simulation Surplus Value for TWP Visitors Gita Nada.

\begin{tabular}{cc}
\hline Bagian/Part & $\begin{array}{c}\text { Nilai Surplus (Rp)/ } \\
\text { Surplus Value (IDR) }\end{array}$ \\
\hline 1 & $(348)$ \\
2 & $(348)$ \\
3 & $(696)$ \\
4 & $(348)$ \\
5 & $(1393)$ \\
6 & 26,045 \\
7 & 52,089 \\
\hline Jumlah/ & $\mathbf{7 5 , 0 0 0}$ \\
Total & \\
\hline
\end{tabular}

Keterangan: * simulasi tarif $(0-\mathrm{Rp} 200,000) /$

Remarks:Tarif Simulation (0-200,000IDR)

Berdasarkan perhitungan simulasi penambahan tarif masuk dalam komponen biaya perjalanan diperoleh nilai surplus Rp75.000. Nilai surplus ini mencerminkan perbedaan keinginan dan kemampuan wisatawan untuk mengeluarkan

Tabel 3. Perhitungan Regresi antara Tingkat Kunjungan per 1000 Penduduk Pada Masing-Masing Zona dengan Biaya Total.

Table 3. Regression Calculation between Visit Rates per 1000 Population in Each Zone with Total Costs.

\begin{tabular}{|c|c|c|c|c|c|}
\hline $\begin{array}{l}\text { Zonal } \\
\text { Zone }\end{array}$ & $\begin{array}{c}\text { Jumlah } \\
\text { Penduduk } \\
\text { (orang) /Total } \\
\text { Population } \\
\text { (person) }\end{array}$ & $\begin{array}{c}\text { Biaya Perjalanan } \\
\text { (Rp)/Travel } \\
\text { Cost (IDR) } \\
\text { (X) }\end{array}$ & $\begin{array}{c}\text { Tingkat } \\
\text { Kunjungan/ } \\
1000 / \text { Visit } \\
\text { Level/1000(Y) }\end{array}$ & $\begin{array}{c}\text { Total Biaya } \\
\text { Perjalanan (Rp)/ } \\
\text { Total Cost (IDR) } \\
\text { (XY) }\end{array}$ & $\mathrm{X}^{2}(\mathrm{Rp}) /(I D R)$ \\
\hline Lombok Barat & 685,161 & 250,000 & 2,000 & $500,000,000$ & $62,500,000,000$ \\
\hline Mataram & 477,476 & 600,000 & 1,000 & $600,000,000$ & $360,000,000,000$ \\
\hline Jumlah & $1,162,637$ & 850,000 & 3,000 & $1,100,000,000$ & $422,500,000,000$ \\
\hline Rataan & 581,319 & 425,500 & 1,500 & $550,000,000$ & $211,250,000,000$ \\
\hline$\alpha$ & \multicolumn{5}{|c|}{$1.324(1500)+(0.00041 \times 425,500)$} \\
\hline$\beta$ & \multicolumn{5}{|c|}{$0.00041((1,100,000.000-(2 * 425,500 * 1500) /(422,500,000,000-(2 * 425,500))$} \\
\hline
\end{tabular}

Sumber:Data Primer Diolah (2020)/ Source: Primary Data Processed, (2020) 
biaya menikmati jasa ekosistem TWP Gita Nada. Pada saat penelitian sudah ada tarif masuk sebesar Rp5000/orang yang digunakan untuk dana kebersihan. Dari simulasi diperoleh total nilai manfaat pariwisata TWP Gita Nada adalah Rp129.667.603.461 dengan luas terumbu karang 1.279 ha dan total pengunjung per 1000 penduduk pada kedua zona adalah sebanyak 1.728.901 orang. Nilai minus pada simulasi menunjukkan bahwa ada perbedaan antara total kesanggungan membayar dengan total biaya yang sebenarnya dibayarkan oleh wisatawan dengan kata lain bahwa wisatawan sanggup untuk membayar lebih besar daripada biaya yang dikeluarkan.

Biaya yang dikeluarkan oleh wisatawan meliputi biaya transportasi, biaya konsumsi, biaya penginapan, biaya penyewaan seperti perahu, alat selam dan snorkling, cinderamata. Biaya transportasi dari tempat tinggal hingga menyewa kapal untuk menyeberang ke gili dengan menyewa kapal wisata yang ada di TWP Gita Nada mencapai $68,2 \%$. Senada dengan hasil penelitian Sari, Rembet \& Sangari (2018) dengan karakteristik wisata alam serupa dengan TWP Gita Nada, biaya transportasi menuju Pulau Lembeh berangkat dari Kota Manado dan sekitarnya berkisar $65,2 \%$. Sebagian besar wisatawan yang berkunjung ke TWP Gita Nada banyak menggunakan transportasi pribadi dan transportasi umum. Transportasi umum biasanya digunakan wisatawan mancanegara yang sebelumnya sudah berwisata di Bali dan melanjutkan perjalanan wisata di Lombok dengan tujuan TWP Gita Nada.

Biaya lainnya yang dikeluarkan adalah biaya penyewaan seperti alat selam dan snorkling. Wisata bawah laut dengan keragaman ikan karang terkonsentrasi di perairan dangkal kurang dari 10 meter memiliki ukuran ikan yang lebih besar jika dibandingkan dengan biomassa ikan di kabupaten lain di Pulau Lombok. Biaya snorkling perorang dengan atraksi memberi makan ikan wisatawan dikenakan biaya Rp35.000 - Rp50.000/orang sedangkan untuk alam selam untuk 2 titik penyelaman dikenakan biaya Rp750.000/orang. Biaya akomodasi meliputi penginapan dan konsumsi berkisar Rp800.000 - Rp1.200.000/orang/hari namun dominan wisatawan yang berkunjung adalah wisatawan harian yang berekreasi rata-rata selama enam - delapan jam.

\section{KESIMPULAN DAN REKOMENDASI KEBIJAKAN}

\section{Kesimpulan}

Kesimpulan yang dapat diambil dari hasil dan pembahasan diatas adalah pola pemanfaatan pariwisata terumbu karang TWP Gita Nada adalah wisata bahari dan wisata pantai. Keberadaan ekosistem terumbu karang sebagai daya tarik TWP Gita Nada memiliki nilai manfaat ekonomi. Berdasarkan analisis ZTCM estimasi total nilai manfaat pariwisata TWP Gita Nada adalah Rp129.667.603.461 dengan luas terumbu karang 1.279 ha dan total pengunjung per 1000 penduduk pada kedua zona adalah sebanyak 1.728.901 orang.

Dalam penelitian ini memberikan gambaran model fungsi permintaan pariwisata TWP Gita sebagai kawasan konservasi perairan yang dikembangkan menjadi pariwisata berkelanjutan. Berdasarkan model fungsi permintaan pariwisata menunjukkan bahwa pertimbangan individu sangat dipengaruhi oleh besaran biaya perjalanan dan karakteristik sosial ekonomi. Namun kelemahan model ini adalah hanya bisa menjelaskan 58,2\% faktor yang memiliki pengaruh terhadap kunjungan wisata TWP Gita Nada. Untuk menjawab 41,8\% yang belum dijelaskan dalam model ini perlu menambah jumlah responden wisatawan.

\section{Rekomendasi Kebijakan}

Dengan mengestimasi nilai manfaat pariwisata terumbu karang TWP Gita Nada akan memberikan gambaran dan meningkatkan kesadaran pentingnya jasa ekosistem TWP Gita Nada. Mengacu hasil analisis ZTCM adalah nilai manfaat pariwisata TWP Gita Nada sebesar Rp129.667.603.461. Estimasi ini bisa menjadi proksi untuk penyusunan rencana strategis pengembangan pariwisata berkelanjutan di TWP Gita Nada yang terkait pada biaya pengelolaan kawasan, biaya mitigasi, biaya perbaikan dan rehabilitasi ekosistem terumbu karang serta biaya kompensasi apabila terjadi kerusakan ekosistem terumbu karang akibat bencana alam atau human error.

Untuk meningkatkan permintaan pariwisata TWP Gita Nada dapat menawarkan atraksi wisata berdasarkan minat wisatawan. Pada saat ini, kecenderungan permintaan pariwisata adalah pariwisata yang peduli dengan isu-isu konservasi dan interaksi dengan komunitas dan budaya lokal. Dalam beberapa kasus industri pariwisata harus 
memiliki pembiayaan untuk melindungi lingkungan dan mengajak wisatawan untuk peduli terhadap kegiatan pelindungan lingkungan di daerah wisata.

Produk wisata TWP Gita Nada kedepan sebaiknya wisata alam yang dikemas menjadi wisata edukasi dengan fokus pada kalangan anak muda yang memiliki minat belajar tinggi. Aksesibiltas menuju lokasi menjadi faktor penting karena kemudahan menuju lokasi akan memberikan pertimbangan positif untuk melakukan kunjungan wisata ke TWP Gita Nada. Pengembangan produk wisata serta merta diikuti dengan peningkatan kualitas sarana dan prasarana. Kondisi sarana dan prasarana yang memadai akan menambah daya tarik TWP Gita Nada dan harus mampu memberikan jaminan $2 \mathrm{H}$ yaitu healthy dan hygiene.

\section{UCAPAN TERIMA KASIH}

Saya ingin mengucapkan terima kasih kepada Dinas Kelautan Perikanan Propinsi Nusa Tenggara Barat, Dinas Pariwisata Kabupaten Lombok Barat, Wildlife Conservation Strategy, Yayasan Deep Blue Sea atas bantuan dan bimbingan dalam penelitian ini. Saya ingin mengucapkan terima kasih kepada dosen pembimbing saya Prof. Nuddin Harahab dan Bapak Andi Kurniawan, Ph.D. yang memberikan masukan untuk kesempurnaan tulisan ini

\section{PERNYATAAN KONTRIBUSI PENULIS}

\begin{abstract}
Dengan ini kami menyatakan bahwa kontribusi masing-masing penulis terhadap pembuatan karya tulis adalah: Cornelia Mirwantini Witomo sebagai kontributor utama dan Nuddin Harahap dan Andi Kurniawan, sebagai kontributor anggota. Penulis menyatakan bahwa telah melampirkan surat pernyataan kontribusi penulis.
\end{abstract}

\section{DAFTAR PUSTAKA}

Arida. N. S. (2016). Dinamika Ekowista Tri Ning Tri di Bali. Denpasar Pustaka Larasan. 337 Halaman

Bayih. B.E \& A. Singh. (2020). Modeling Domestic Tourism: Motivation, Satisfaction, and Tourist Behavioral Intentions. Heliyon, 6 (2020) e04839. 17 Halaman.

Budiman. R. O. (2019). Valuasi Ekowisata Mangrove Dengan Travel Cost Method (TCM) (Studi Kasus Taman Wisata Alam Mangrove Angke Kapuk Jakarta Utara. (Skripsi). Jurusan Sosial Ekonomi Agrobisnis Perikanan Fakultas Perikanan dan Ilmu Kelautan.
Costanza. R., R. De Groot, P. Sutton., S. Van Der Ploeg., S. J. Anderson., I. Kubiszewski., S. Farber., R. K. Tunner. (2014). Changes In The Global Value of Ecosystem Services. Global Environmental Change 26 (2014). pp. 152-158.

Costanza. R., R. DeGroot., L. Braat., I. Kubiszewski., L. Fioramonti., P. Sutton., S. Farber \& M. Graco. (2017). Twenty Years of Ecosystem Services: How Far Have We Come and How Far Do We Still Need To Go. Ecosystem Services, 28 (2017). pp 1-16.

Dinas Pariwisata Kabupaten Lombok Barat. (2019). Profil Dinas Pariwisata Kabupaten Lombok Barat Tahun 2019. Dinas Pariwisata Kabupaten Lombok Barat, Gerung. 36 Halaman

Ezebilo. E.E. (2016). Economic Value of a non-market ecosystem service : an Application of The Travel Cost Method to Nature Recreation in Sweden. International Journal of Biodiversity Science, Ecosystem Service and Management 12:4. pp. 314-327.

Fadli. I. (2016). Pengaruh Likuiditas, Leverage, Komisiaris Independen, Manajemen Laba, dan Kepemilikan Institusional, Terhadap Agresivitas Pajak Perusahaan (Studi Pada Perusahaan Manufaktur yang Terdaftar di Bursa Efek Indonesia Periode 2011 - 2013). JOM Fekon Volume 3 Nomor 1 (Februari) 2016. Hal. $1205-1219$.

Farahani. H.A., A. Rahiminezhad., L. Same \& K. Immannezhad. (2010). A Comparison of Partial Least Squares (PLS) and Ordinary Least Squares (OLS) Regressions in Predicting of Couple Mental Health Based On Their Communication Patterns. Procedia Social and Behavioral Science, 5 (2010). pp. 1459-1463.

Fleming. C. M \& A. Cook. (2008). The Recreational Value of Lake McKenzie, Frazer Island: An Application of The Travel Cost Method. Tourism Management, 29 (2008). pp 1197 - 1205.

Giyanto., M. Abrar., T. A. Hadi., A. Budiyanto., M. Hafizt., A. Salatalohy \& Iswari .M. Y. Iswari. (2017). Status Terumbu Karang Indonesia 2017. ISBN 978-601-6664-09-9. Coremap-CTI Pusat Penelitian Oseanografi LIPI Jakarta. 41 Halaman.

Gossling.S., A. Ring., L. Dwyer., A.C. Andersson dan \& M Hall. (2015). Optimizing or Maximizong Growth? A Challenge For Sustainable Tourism. Journal of Sustainable Tourism Volume 24(4) 2016. DOI:10.1080/09669582.2015.1085869. 23 pages.

Govigli. V. M., E. Gorriz-Mifsud. \& E. Varela. (2019). Zonal Travel Cost Approaches To Assess Recreational Wild Mushroom Picking Value: Trade-offs Between Online and Onsite Data Collection Strategies. 
Grigalunas. T.A \& R. Congar. (1995). Environmental Economics For Integrated Coastal Area Management Valuation Methods and Policy Instruments. UNEP Regional Seas Report and Studies No 164. ISBN 92-807-1488-0. 175 pages.

Gujarati. D. N \& D. C. Porter. (2015). Dasar-Dasar Ekonometrika Edisi 5 Buku 1. Jakarta. Salemba Empat. ISBN 978-979-061-065-1. 686 halaman.

Hilmi. N., A. Safa., U. R. Sumalia \& M. Cinar. (2017). Coral Reef Management and Decision Making Tools. Ocean \& Coastal Management. 146. pp $60-66$.

Kementerian Pariwisata. (2015). Rencana Strategis Pengembangan Destinasi dan Industri Pariwisata Kementerian Pariwisata Tahun 2015-2019. 70 Halaman.

Keputusan Menteri Kelautan Perikanan No 93/ KepmenKP Tahun 2018 Tentang Kawasan Konservasi Perairan Gili Tangkong, Gili Nanggu, Gili Sudak, Dan Perairan Sekitarnya Di Provinsi Nusa Tenggara Barat.

Lankia. T., M. Neuvonen \& E. Pouta. (2017). Effect of Water Quality Changes on The Recreation Benefit of Swimming in Finland: Combined Travel Cost and Contingent Behavior Model. Water Resources and Economics (2017).

Loomis.J., O. Tadjion., P. Watson., J. Wilson., S. Davies \& D. Thilmany. (2009). A Hybrid IndividualZonal Travel Cost Model For Estimating The Consumer Surplus of Golfing in Colorado. Journal of Sport Economics Volume, 10(2) April 2009. pp. 155-167.

Lundevaller. E. H. (2009). The Effect of Travel Cost Frequencies of Shopping and Recreational Trips in Sweden. Journal of Transport Geography, 17 (2009). pp. $208-215$.

Luthfi. O.M \& I. N. Januarsa. (2018). Identifikasi Organisme Kompetitor Terumbu Karang Di Perairan Pantai Putri Menjangan, Buleleng, Bali. Jurnal Kelautan Volume 11 Nomor 1 2018. ISSN 1907-9931. Hal. 24-30

Mayer. M \& M. Woltering. (2018). Assessing and Valuing The Recreational Ecosystem Services of Germany's National Park Using Travel Cost Models. Ecosystem Services, pp 1 -16.

Melstrom. R. T. (2014). Valuing a historic site with multiple visitor types and missing survey data. Journal of Cultural Heritage. pp 1 -4.

Mulyati. Y \& Masruri. (2019). Analisis Faktor-Faktor Yang Mempengaruhi Keputusan Berkunjung Wisatawan Domestik Ditinjau Dari Perspektif Daya Tarik Destinasi Wisata Kota Bukittinggi. Menara IImu, 13(1) Januari 2019. Hal 190-205.
Nadia. A.N. (2017). Valuasi Ekonomi Menggunakan Travel Cost Method Pada Objek Wisata Bahari Lamongan (WBL) Kabupaten Lamongan. (Skripsi). Jurusan Sosial Ekonomi Agrobisnis Perikanan Fakultas Perikanan dan Ilmu Kelautan.

Oktaviani. M. A \& H. B. Notobroto. 2014. Perbandingan Tingkat Konsistesi Normalitas Distribusi Metode Kolmogorov-Smirnov, Lilliefor, Shapiro-Wilk dan Skewness-Kurtosis. Jurnal Biometrika dan Kependudukan Volume 3 No 2 Desember 2014. pp 127-135.

Pardede, S., E. Muttaqin., S.A.R. Tarigan \& S. Sadewa. S. (2014). Status Ekosistem Terumbu Karang Di Pulau Lombok 2013 : Dalam Mendukung Perancangan Zonasi dan Pengelolaan Kawasan Konservasi Perairan Daerah di Provinsi Nusa Tenggara Barat. Bogor. Wildlife Conservation Society, Bogor. 89 Halaman

Peraturan Bupati Lombok Barat No 56 Tahun 2011 Tentang Pencadangan Kawasan Konservasi Laut Daerah Kabupaten Lombok Barat.

Pirikiya. M., H. Amirnejad., J. Oladi \& K. A. Solout. (2016). Determining The Recreational Value Of Forest Park By Travel Cost Method and Defining its Effective Factors. Journal of Forest Science 62 2016 (9). pp 399 - 406.

Sari, E. S. (1993). Audience Research : Pengantar Studi Penelitian Terhadap Pembaca, Pendengar dan Permirsa. Yogyakarta. Andi Offset.

Sari. M. P., U. N. W. J. Rembet \& J. R. R. Sangari. (2018). Valuasi Ekonomi Kawasan Ekowisata Pasirpanjang di Pulau Lembeh. Jurnal IImiah Platax, 6(2) Juli 2018. Hal 24-37\

Selig. E.R., D. G. Hole., E. H. Allison., K. K. Arkema., M. C. McKinnon., J. Chu., A. de Sherbinin, B. Fisher., L. Gallagher., M. B. Holland., J. C. Ingram., N. S. Rao., R. B. Russel., T. Srebotnjak., L. C. L. The., S. Troeng., W. R. Tunner \& A. Zvoleff. (2018). Mapping Global Human Dependence on Marine Ecosystem. Conservation Letter 2018. pp 1-10.

Sugiarto., T. Hendratono \& D. Sudibyo. 2015. Metodologi Penelitian Hospitaliti dan Pariwisata. Cetakan 1. ISBN 978-602-72268-9-0. Tangerang. PT Matana Publishing Utama. 482 Halaman.

Supriyadi. E. 2016. Perbandingan Metode Partial Least Square (PLS) dan Principal Component Regression (PCR) Untuk Mengatasi Multikolinearitas Pada Model Regresi Linear Berganda. (Skripsi). Jurusan Matematika Fakultas Matematika dan IImu Pengetahuan Alam Universitas Negeri Semarang. 64 Halaman.

Suwena. I.K dan I.G.N. Widyatmaja. 2017. Pengetahuan Dasar IImu Pariwisata. Edisi Revisi. Slamat Trisila. Denpasar Bali. ISBN 9786025401046. 248 Halaman. 
Surat Keputusan Gubenur NTB 523-640 Tahun 2018 tentang Pencadangan Kawasan Konservasi Perairan, Pesisir dan Pulau-pulau Kecil Provinsi NTB

Utari. P.S \& Kampana. I. M. A (2014). Perencanaan Fasilitas Pariwisata (Tourism Amenities) Pantai Pandawa Desa Kutuh Kuta Selatan Badung. Jurnal Destinasi Pariwisata Volume 2 Nomor 1 2014. ISSN 2338-8811. pp 57-67

Yulianto, E. Y. F., W. Mawardi \& F. Purwangka. (2018). Penentuan Lokasi Penangkapan Ikan Karang di Kawasan Konservasi Perairan Gita Nada, Lombok Barat. Jurnal IPTEKS PSP, 5(10) Oktober 2018. 